\title{
Glacial goemorphology in the Lunana area in the Bhutan Himalaya: Moraine stages, glacial lakes, and rock glaciers
}

\author{
Shuji Iwata†*, Karmał, Yutaka Ageta§, Akiko Sakai§, Chiyuki Narama§ and Nozomu Naito ฯ \\ † Department of Geography, Tokyo Metropolitan University, Tokyo,192-0397 JAPAN \\ \# Geological Survey of Bhutan, PO Box 173, Thimphu, BHUTAN \\ $\$$ Graduate School of Environmental Studies, Nagoya University, Chikusa, Nagoya, 464-8601 JAPAN \\ ฯ Faculty of Environmental Studies, Hiroshima Institute of Technology, Hiroshima, 731-5193 JAPAN \\ *To whom correspondence should be addressed.E-mail address: iwata-s@comp.metro-u.ac.jp
}

Although the first report by Augusto Gansser with beautiful photographs on the glacial lakes in Lunana of the Bhutan Himalayas attracted considerable attention in the 1970s (Gansser 1970), the Lunana area was left by any scientific research for many years after the Gansser's visit. In 1994, as per Gansser's prediction, a glacial lake outburst flood (GLOF) occurred in the Lunana area and killed over 20 persons in the downstream area. The Bhutanese Government and scientists started monitoring and scientific researches of glaciers, glacial lakes, and related phenomenon in the Lunana area from 1995. The Bhutan-Japan Joint Research on the Assessment of GLOF started research from 1998 and continues at present. The present authors took part in the project. In this paper, they present analyses and discussion on the timing and extent of glacial fluctuations for selected glaciers, risk of some glacial lakes and permafrost and related phenomena and importance of these phenomenon in the Lunana area.

The Lunana area is a basin with the altitudes of 4300-4500 $\mathrm{m}$ between the main Himalayan divide and mountains and plateau with 5000-5500 $\mathrm{m}$ in altitudes to the south. Figure 1 shows moraines, glaciers, and glacial lakes around Thanza village in the eastern part of the Lunana basin. Contemporary glaciers are common on the main divide of the Bhutan Himalayas to the north of Lunana. The large glaciers are located in the Lunana basin, while smaller glaciers are on plateaus that stretch to the south from the Lunana basin. Moraines in the Thanza Village area, Lunana, constitute three distinct stages with contrasts of spatial situations and volume of moraines, and surface features such as clasts, soils, and vegetation. These three stages correlate with some glacial stages in the Khumbu Himal, eastern Nepal, using morphostratigraphic criteria (Iwata 1976). Dates of moraines in the Khumbu Himal (Richards et al. 2000) provide a tentative chronological sequence of these three stages. Valley glaciers in Lunana expanded during the following periods: (1) the Raphsthreng Stages related to the Little Ice Age and late Holocene glacial advances, (2) the Tenchey Stages represent the Late Glacial and/or early Holocene glacial advances, (3) the Lunana Stages are coincident with the Last Glacial period.

00GLOF events have been common phenomena in the Lunana area in the past 50 years, and have been accelerated in the recent years. Field observations and investigation by map and satellite images indicate that most supraglacial lakes tend to connect each other and grow up to a large lake rapidly, and some moraine-dammed lakes were formed and rapidly expanded after the 1970s due to retreating and/or melting of glaciers (Figure 2). Rates of the glacial lake expansion vary with individual lakes. The largest mean annual rate is $160 \mathrm{~m}$ year-1 $^{-1}$ for Lugge Tsho between 1988 and 1993. Ageta et al. (2000) concluded that the mean annual expansion rates fall within a range of
30-35 m year ${ }^{-1}$. Assessment on occurrence of triggers, impact to the lakes, and vulnerability of moraine-dams suggests that there are at least 3 potential dangerous glacial lakes in the Lunana area. Dangerous glacial lakes are Lugge Tsho, Raphsthreng Tsho, and Thorthomi Tsho in eastern Lunana. Since these three glacial lakes still contain a large volume of water, and are bounded each other and interact sensitively through water flux and erosion. Constant and regular monitoring of glaciers and glacial lakes are urgently required to prepare necessary mitigation activities.

Rock glaciers and periglacial features exist in many places in Lunana. The distribution of active periglacial rock glaciers suggests that the lower limit of discontinuous permafrost is at $4800 \mathrm{~m}$ on north-facing slopes and at $5000 \mathrm{~m}$ on south- to eastfacing slopes. Results of automatic weather-station measurements suggest that mean annual air temperatures at the lower limits of the permafrost zone are $-1.1^{\circ} \mathrm{C}$ at $5000 \mathrm{~m}$ and $+0.1{ }^{\circ} \mathrm{C}$ at $4800 \mathrm{~m}$. Some periglacial features, such as earth hummocks, debris islands, and rubble and block slopes indicate that the periglacial environment in the Bhutan Himalayas is very similar to that of the Khumbu Himal in eastern Nepal.

The equilibrium line altitudes of glaciers (ELAs) and lower limit of discontinuous permafrost in the Lunana area are lower than those in eastern Nepal. This lower expansion of these boundaries may be caused by much precipitation and diminished solar radiation in summer due to the monsoon bad weather during monsoon season. Glacier terminus and moraine dams that form glacial lakes in the Lunana basin are situated at around $4400 \mathrm{~m}$. These elevations are about $1000 \mathrm{~m}$ lower than those in Khumbu, eastern Nepal, and are apparently at lower altitudes than the lower limit of discontinuous permafrost. This suggests that the melting rates of glaciers are higher rates than that in Khumbu and ice core of moraine dams melts soon after glacier retreat. The vulnerability of the ice-cored moraines in Lunana is greater than those in Khumbu.

\section{References}

Ageta Y, S Iwata, H Yabuki, N Naito, A Sakai, C Narama and Karma. 2000 Expansion of glacier lakes in recent decades in the Bhutan Himalayas. In: Nakawo M, CF Raymond and A Fountain (eds): Debris-Covered Glaciers (Proceedings of a workshop held at Seattle, Washington, USA, September 2000). IAHS Publ. no. 246: 165-75

Gansser A. 1970. Lunana: the peaks, glaciers and lakes of northern Bhutan. The Mountain World 1968/69: 117-31

Iwata S. 1976. Late Pleistocene and Holocene moraines in the Sagarmath (Everest) region, Khumbu Himal. Seppyo. Japanese Journal of Snow and Ice Special Issue 38: 109-114

Richards BWM, DI Benn, LA Owen, EJ Rhodes and JQ Spencer. 2000. Timing of late Quaternary glaciations south of Mount Everest in the Khumbu Himal, Nepal. Geological Society of America, Bulletin 112: 1621-1632 


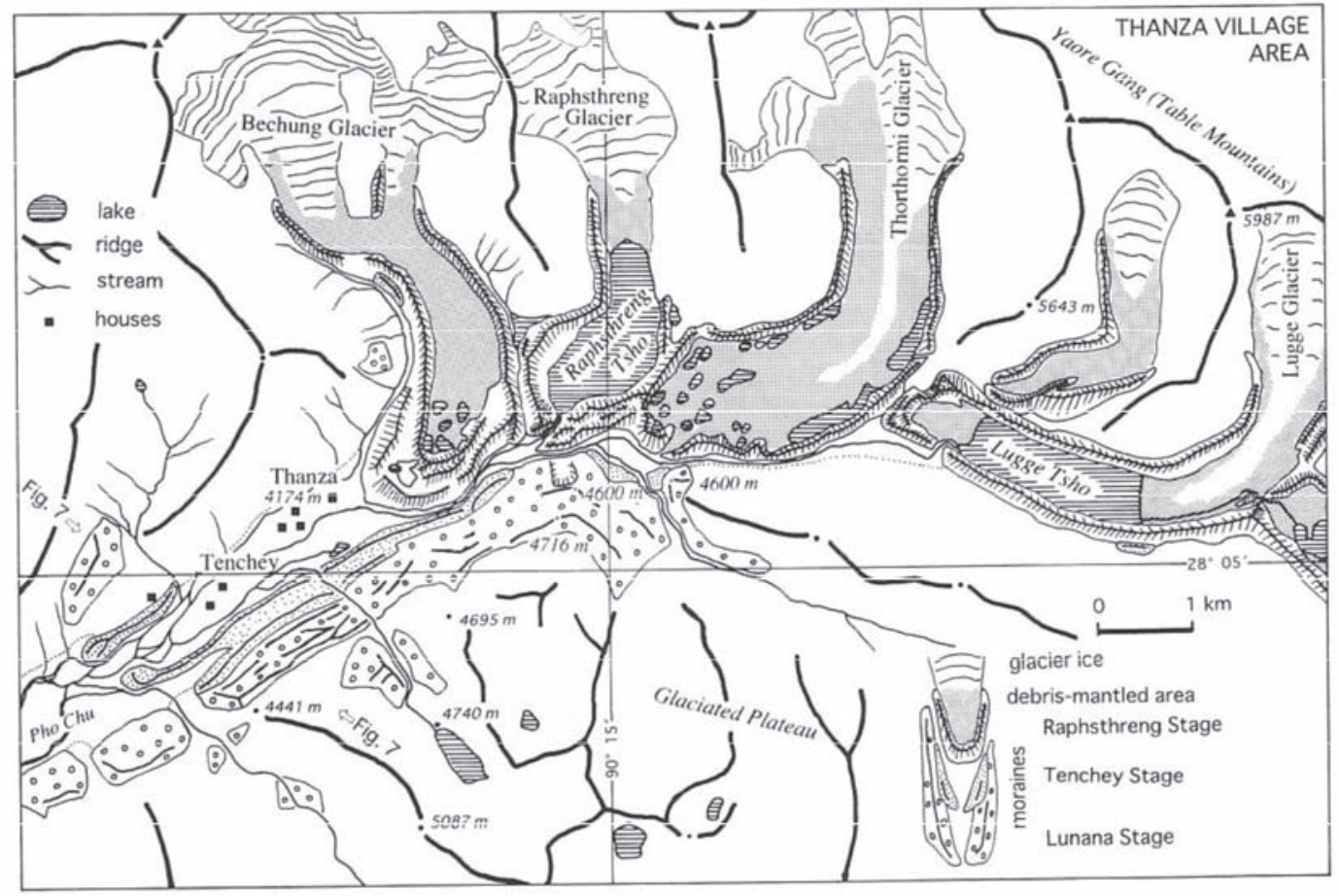

FIGURE 1. Geomorphological map of the area around Thanza Village (4170 $\mathrm{m}$ asl) in the eastern part of the Lunana basin, northern Bhutan

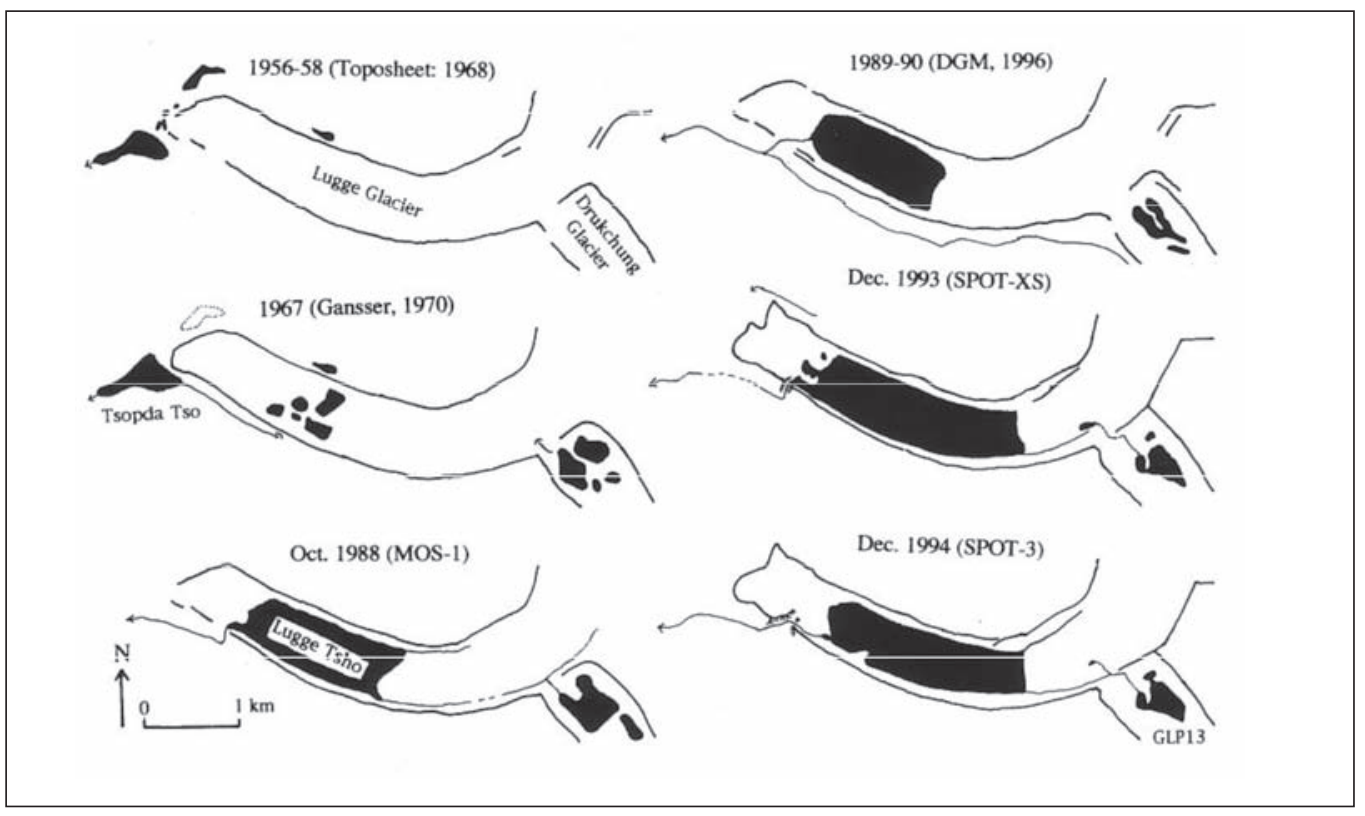

FIGURE 2. Expansion of Lugge Tsho (Lake), Tsopda Tsho, and Drucchung in the Lunana area, Bhutan Himalaya (Ageta et al. 2000) 